Kelola

Jurnal Manajemen Pendidikan

Magister Manajemen Pendidikan

ISSN 2443-0544

FKIP Universitas Kristen Satya Wacana

Volume: 3, No. 1, Januari-Juni 2016

jurnalkelola@gmail.com

Halaman: $30-48$

\title{
PENGEMBANGAN MODEL SUPERVISI AKADEMIK TEKNIK MENTORING BAGI PEMBINAAN KOMPETENSI PEDAGOGIK GURU KELAS
}

\author{
Nehtry.E.M.Merukh \\ Alumni Program Pascasarjana Magister Manajemen Pendidikan \\ FKIP-Universitas Kristen Satya Wacana \\ nehtry.merukh@yahoo.co.id; \\ Bambang Suteng Sulasmono \\ Program Pascasarjana Magister Manajemen Pendidikan \\ FKIP-Universitas Kristen Satya Wacana \\ bambang.sulasmono@staff.uksw.edu
}

\begin{abstract}
This research aimed to describe (1) Implementation of principal supervision at Tunas Gloria Elementary School, Kupang; (2) Problems in the implementation of principal supervision at Tunas Gloria Elementary School, Kupang; and (3) Creating of the academic supervision models of pedagogic competence guidance mentoring technique for homeroom teacher. This research is $\mathrm{R} \& \mathrm{D}$ (Research and Development) by following steps of development according to Sugiono (2009). Questionnaires, interviews and documentation studies were used as data collection techniques. Delphie technique was used as model validation. Results of research showed that (1) Implementation of principal supervision has not been performed according to principles of supervision performance, (2) problems in the implementation of principal supervision i.e. a written planning has not been made; purposes of supervision has not been constructed according to the needs of teachers; guidance for supervision performance was still insufficient; time demand for principal; the performance of supervision was only adjusted to the supervision of supervisor; the comprehension from principalin performing of evaluation. The final result was in the form of academic supervision models of pedagogic competence guidance mentoring technique for homeroom teacher that consists of 4 stages-planning, performance, evaluation and follow-up.
\end{abstract}

Key words: Academic supervision, mentoring, pedagogic competence

\section{PENDAHULUAN}

Undang-undang Republik Indonesia Nomor 14 Tahun 2005 tentang Guru dan Dosen pasal 20 ayat (b) mengamanatkan bahwa dalam rangka melaksanakan tugas profesional nya, guru berkewajiban meningkatkan dan mengembangkan kualifikasi akademik dan kompetensi secara berkelanjutan sejalan dengan perkembangan ilmu pengetahuan, teknologi, dan seni. Dalam hal ini, guru wajib memiliki: (i) kualifikasi akademik minimal S1 atau D-IV; (ii) kompetensi sebagai agen pembelajaran yaitu kompetensi pedagogik, kepribadian, sosial, dan 
profesional; (iii) sertifikat pendidik. Hal ini menjadi suatu ketetapan politik yaitu pendidik adalah pekerja profesional yang berhak mendapatkan hak-hak sekaligus kewajiban profesional (Mulyasa, 2013).

Kenyataannya dalam menjalankan tugas profesional, menurut Danim (2010) guru belum menunjukkan kinerja (work performance) yang memadai. Hal ini nampak dalam hal: (1) kemampuan siswa kurang maksimal dalam menyerap mata pelajaran yang diajarkan guru; (2) kurang sempurnanya pembentukan karakter yang tercermin dalam sikap dan kecakapan hidup setiap siswa; dan (3) rendahnya kemampuan membaca, menulis dan berhitung siswa di tingkat dasar (Slameto, 2013). Selanjutnya, Slameto menambahkan rendahnya kinerja guru dikarenakan belum adanya pembinaan kompetensi guru yang mencerminkan kebutuhan.

Menindaklanjuti akan permasalahan guru dalam menjalankan tugas profesional, pemerintah melakukan usaha perbaikan dengan memprogramkan kegiatan pengembangan kompetensi guru. Salah satu contoh kegiatan peningkatan kinerja guru yaitu melalui bantuan supervisor, orang yang melaksanakan kegiatan supervisi terhadap guru (Mukhtar \& Iskandar, 2010). Sagala (2010) menyatakan supervisi pendidikan adalah upaya perbaikan pengajaran sebagai langkah pertumbuhan jabatan profesional guru yang berintegrasi pada kebutuhan individu dengan tujuan pendidikan dan tugas-tugas pokok sekolah. Lebih khusus Sagala mendefinisikan supervisi akademik adalah untuk membantu guru-guru belajar bagaimana meningkatkan kemampuan dan kapasitasnya, agar peserta didiknya dapat mewujudkan tujuan belajar yang telah ditetapkan.

Terdapat sejumlah penelitian yang relevan dengan penelitian pengembangan yang hendak dilakukan. Pertama, penelitian Prihono (2014) yang berjudul 'Model Supervisi Akademik Berbasis Evaluasi Diri Melalui MGMP Sekolah Untuk Meningkatkan Kompetensi Pedagogik Guru SMK Di Kabupaten Wonogiri' menunjukkan bahwa model supervisi akademik berbasis evaluasi diri efektif meningkatkan kompetensi pedagogik guru SMK di kabupaten Wonogiri. Hal ini terlihat pada perubahan atau peningkatan kompetensi pedagogik guru setelah diberikan supervisi hasil pengembangan. Kedua, penelitian Mailani (2014) yang berjudul 'Upaya Pembinaan Kompetensi Pedagogik Guru dalam Menyusun Rencana Pelaksanaan Pembelajaran melalui Kegiatan Pendampingan (Mentoring)'”. Hasil penelitian ini menunjukkan adanya keberhasilan kegiatan mentoring dalam upaya meningkatkan kompetensi pedagogik guru dalam menyusun rencana pembelajaran. Ketiga, penelitian Sharma et al (2011) yang berjudul "Concerns of Teachers and Principals on Instructional 
Pengembangan Model Supervisi Akademik Teknik Mentoring Bagi Pembinaan Kompetensi Pedagogik Guru Kelas | Nehtry E M Merukh \& Bambang Suteng Sulasmono

Supervision in Three Asian Countries". Penelitian ini bertujuan untuk mendeskripsikan sifat instruksional supervisi yang dilakukan di sekolah-sekolah di tiga negara Asia yaitu India, Malaysia dan Thailand. Hasil penelitian menunjukkan bahwa peran pengawas hanya untuk mencari kesalahan guru dan bukan meningkatkan kinerja guru. Penelitian ini menyebutkan jika guru lebih suka supervisi yang melibatkan mereka.

Hasil penelitian-penelitian terdahulu di atas menunjukan bahwa 1) pelaksanaan supervisi belum maksimal karena jumlah pengawas dan guru tidak sebanding, 2) pelaksanaan supervisi hanya mencari kesalahan, 3) guru belum dilibatkan secara aktif dalam supervisi, 4) guru membutuhkan mentoring dalam pelaksanaan supervisi. Hal serupa juga terjadi di SD kristen Tunas Gloria Kupang, berdasarkan observasi awal tentang pelaksanaan supervisi menunjukkan bahwa supervisi belum dilakukan secara berkala. Dalam pelaksanaannya hanya sebagian guru kelas yang di supervisi. Selain itu, kepala sekolah belum memiliki program yang menggambarkan model supervisi yang akan dilaksanakan. Padahal, Muslim (2010) menyatakan keefektifan supervisi memerlukan satu program yang memuat berbagai aktivitas atau kegiatan yang akan dikerjakan oleh supervisor. Program dibutuhkan untuk menggambarkan apa yang akan dilakukan, cara melakukan, waktu pelaksanaan dan cara mengukur keberhasilan pelaksanaannya. Gambaran pelaksanaan supervisi di atas tentu bertentangan dengan Peraturan Pemerintah No. 28 tahun 1990 tentang pendidikan dasar yang menyebutkan bahwa kepala SD bertanggung jawab atas pembinaan tenaga kependidikan.

Pelaksanaan supervisi kepala sekolah yang belum dijalankan dengan baik ini berakibat pada kinerja guru kelas di SD Kristen Tunas Gloria. Berdasarkan data penilaian kompetensi pedagogik guru kelas menunjukkan bahwa dari skor 4 rerata guru kelas hanya berada pada skor 2,71 dan rata-rata skor terendah guru kelas terletak pada indikator penilaian dan evaluasi. Selain itu, check list kelengkapan Silabus dan RPP guru kelas menunjukkan belum semua memilki kelengkapan. Dari sebelas orang guru kelas ternyata hanya 2 orang yang memiliki kelengkapan RPP dan silabus. Sedangkan yang lain, hanya memiliki 2 sampai 4 RPP dan silabus dari total 8. SD Kristen Tunas Gloria menggunakan kurikulum 2013 sehingga RPP dan silabus yang dirancang oleh guru kelas adalah tematik dan berbasis tema.

Tentang mentoring, Widysari dan Yaumi (2014) menyatakan bahwa mentoring dapat dilakukan ketika tingkat kinerja dan motivasi guru perlu diperbaiki. Sedang pengertian mentoring menurut Federal Chief Information Officers Council (dalam Chick et al, 2013) yaitu 'mentoring is a developmental process in which a more experienced individual commits to working and learning with a less experienced individual for the purpose of 
improving the professional development of both individuals', Jadi mentoring adalah proses perkembangan dimana individu yang lebih berpengalaman berkomitmen untuk bekerja dan belajar dengan individu yang kurang berpengalaman dengan tujuan untuk meningkatkan pengembangan profesionalisme kedua individu. Lebih lanjut Chick et all (2013) menambahkan tujuan dari mentoring yaitu memungkinkan individu untuk menetapkan dan mencapai tujuan yang membangun pada apa yang sudah diketahui tetapi belum bisa dicapai sendiri dan secara bertahap meningkatkan kemampuan individu dalam praktik sampai mampu untuk melakukan semua fungsi yang diperlukan tanpa bimbingan atau supervisi.

Mentoring jika diterapkan dalam pelaksanaan supervisi kepala sekolah tentu akan memberikan perbaikan dalam kompetensi pedagogik guru kelas. Melihat pada tujuan dari mentoring itu sendiri yaitu meningkatkan kemampuan individu secara bertahap sampai mampu dan mandiri dalam melakukan semua fungsi yang diperlukan. Hal ini berarti ada jaminan keberhasilan dari supervisi yaitu pelaksanaannya akan dilakukan bertahap sampai guru dapat melakukan semua tugas profesional guru secara mandiri tanpa bimbingan ataupun supervisi kepala sekolah. Karena pelaksanaan dilakukan secara bertahap maka perlu adanya model supervisi untuk membantu kepala sekolah dalam memahami dan melaksanakan tugas dan fungsinya sebagai supervisor serta pembelajaran apa yang dibutuhkan untuk melakukan pembinaan kompetensi pedagogik guru kelas.

Berdasarkan latar belakang di atas maka rumusan masalah dalam penelitian ini adalah 1) Bagaimana praktik supervisi kepala sekolah di SD Kristen Tunas Gloria Kupang, 2) Apa masalah dalam pelaksanaan supervisi kepala sekolah di SD kristen Tunas Gloria Kupang, dan 3) Bagaimana model supervisi akademik teknik mentoring pembinaan kompetensi pedagogik guru kelas. Penelitian ini bertujuan untuk 1) Mendeskripsikan praktik supervisi kepala sekolah di SD Kristen Tunas Gloria Kupang, 2) Mendeskripsikan masalah dalam pelaksanaan supervisi kepala sekolah di SD Kristen Tunas Gloria Kupang, dan 3) Menghasilkan model supervisi akademik teknik mentoring untuk pembinaan kompetensi pedagogik guru kelas. Hasil penelitian ini diharapkan dapat memberikan kontribusi bagi sekolah berupa model supervisi akademik teknik mentoring dan menjadi referensi bagi penelitian selanjutnya.

\section{METODE PENELITIAN}

Penelitian ini adalah penelitian pengembangan (Research and Development). Model pengembangan mengikuti prosedur R \& D yang dikembangkan oleh Sugiyono (2009) yang terdiri atas 10 tahap metode pengembangan yaitu (1) Potensi dan masalah, (2) Pengumpulan 
data, (3) Desain produk, (4) Validasi desain, (5) Revisi desain, (6) Uji coba produk, (7) Revisi produk, (8) Uji coba pemakaian, (9) Revisi produk, dan (10) Produk masal. Berdasarkan alur langkah penelitian R\&D tersebut maka penelitian ini hanya sampai pada langkah kelima yaitu revisi desain.

Penelitian dilakukan di SD Kristen Tunas Gloria Kupang yang terletak di Jalan H.R. Koroh No. 172 Sikumana, Maulafa Kupang-NTT pada bulan Desember 2015 sampai Januari 2016. Subyek penelitian yaitu kepala sekolah dan guru kelas SD Kristen Tunas Gloria Kupang. Teknik dan alat pengumpulan data menggunakan kuesioner, wawancara dan studi dokumentasi. Prosedur penelitian terdiri atas 5 tahapan yaitu: 1) Studi Awal (Pendahuluan), peneliti melakukan studi pendahuluan tentang potensi dan masalah yang ada di SD Kristen Tunas Gloria Kupang. Studi pendahuluan dilakukan dengan wawancara terhadap kepala sekolah, pengisian kuesioner oleh guru kelas dan studi dokumentasi tentang profil, format penilaian kompetensi pedagogik guru kelas dan form pelaksanaan supervisi, 2) Pengumpulan Data, peneliti melakukan pengumpulan data berupa hasil penelitian dari studi literatur yang dilakukan melalui studi kepustakaan (book survey) tentang model supervisi bagi kepala sekolah, 3)Pengembangan Desain, peneliti mengembangkan desain panduan mentoring berdasarkan hasil studi awal dan pengumpulan data. Model supervisi yang dikembangkan yaitu model supervisi akademik teknik mentoring pembinaan kompetensi pedagogik guru kelas, 4) Validasi Desain, tahapan validasi atau penilaian dari para ahli menggunakan teknik delphi dengan media kuesioner. Sedikitnya dilakukan dua putaran (two-round) delphi untuk menghasilkan desain model supervisi akademik teknik mentoring guru kelas yang baik. Validasi produk dilakukan dengan menghadirkan dua orang dosen ahli dan Kepala Sekolah SD Kristen Tunas Gloria Kupang sebagai pengguna dari model supervisi akademik teknik mentoring, dan 5) Revisi Desain, hasil dari penilaian pakar tentang model supervisi akademik teknik mentoring ditindaklanjuti dengan melakukan perbaikan pada model.

\section{HASIL DAN PEMBAHASAN}

Berdasarkan desain penelitian dan pengembangan yang telah dipaparkan, penelitian ini terdiri atas 5 tahapan. Meliputi 1) Studi Pendahuluan (potensi dan masalah), 2) Pengumpulan data, 3) Desain Produk, 4) Validasi Desain, 5) Perbaikan Desain.

1. Potensi dan Masalah

Tahap potensi dan masalah dilaksanakan dengan studi pendahuluan melalui studi dokumentasi, wawancara dan kuesioner. Berdasarkan hasil studi pendahuluan diketahui bahwa potensi dalam perencanaan supervisi yang dilakukan oleh kepala sekolah terletak pada sumber yang digunakan sebagai acuan dalam melakukan perencanaan yaitu instrumen dari 
dinas dan panduan yayasan tahun 2012, sebagaimana yang diungkapkan oleh kepala sekolah pada saat wawancara :

'Acuan yang saya pakai yaitu instrumen supervisi yang saya dapatkan dari dinas dalam bentuk instrumen-instrumen seperti instrumen perencanaan kegiatan pembelajaran, instrumen observasi kelas, instrumen pendampingan pelaksanaan pembelajaran (peer teaching) dan instrumen pendampingan telaah RPP. Kemudian ada juga panduan supervisi yayasan tahun 2012 yang saya pakai sebagai contoh.", (wawancara tanggal 21 Desember 2015)

Selain acuan dari dinas maupun panduan supervisi yayasan, kepala sekolah juga melakukan studi pendahuluan sebagai bagian dari perencanaan. Bentuk perencanaannya melalui observasi kegiatan belajar mengajar (KBM) dan sharing bersama guru dalam rapat kerja (raker). Sebagaimana disampaikan oleh kepala sekolah :

\footnotetext{
"Saya melakukan perencanaan setiap awal tahun ajaran. Bentuk perencanaannya melalui observasi KBM saat guru sedang melaksanakan kegiatan pembelajaran. Kemudian bentuk perencanaan lain melalui sharing dengan guru dalam raker sekolah. Biasanya guru menyampaikan permasalahan yang dialami dalam kegiatan pembelajaran yang nantinya menjadi input untuk saya', (wawancara tanggal 21 Desember 2015).
}

Observasi kepala sekolah sebagai bentuk perencanaan juga disampaikan oleh guru kelas dalam kuesioner. Hanya menurut guru kelas bentuk observasi masih berupa himbauan. Berikut yang disampaikan oleh guru kelas: "ya, agar mempersiapkan perlengkapan mengajar', (kuesioner guru kelas, 2016).

Pada pelaksanaan supervisi potensi yang ada terletak pengawasan tentang pengawasan supervisi yang dilakukan oleh dinas secara berkala. Seperti yang diungkapkan oleh kepala sekolah: "'faktor eksternal menurut saya karena adanya pengawasan atau supervisi berkala dari dinas yang membuat guru harus siap ketika di supervisi', (wawancara tanggal 21 Desember 2015).

Pada pelaksanaan evaluasi supervisi kepala sekolah disebutkan tentang evaluasi bertahap yang dilakukan sambil melihat perkembangan dari guru yang di supervisi itu sendiri. Hal ini diungkapkan oleh kepala sekolah bahwa:

\footnotetext{
"evaluasi saya lakukan secara bertahap, biasanya kegiatan evaluasi tersebut diadakan rutin dengan melihat perkembangan dari guru yang bersangkutan misalnya setelah $2 x$ pertemuan dengan guru tersebut saya lihat sudah ada perkembangan maka saya anggap guru tersebut paham sehingga saya tidak melakukan sampai guru benar-benar tanggap. (wawancara tanggal 21 Desember 2015).
}

Bentuk evaluasi supervisi kepala sekolah juga dibenarkan oleh guru kelas yaitu: "ya, kepala sekolah menanyakan tentang kendala yang dihadapi di kelas dan juga memberikan motivasi"' (kuesioner guru kelas, 2016). 
Masalah yang ditemukan pada bagian perencanaan yaitu yang pertama, belum ada panduan khusus yang dibuat oleh kepala sekolah walaupun sudah ada instrumen dari dinas dan panduan supervisi yayasan tahun 2012. Dalam wawancara yang telah dilakukan kepala sekolah mengungkapkan bahwa: "Untuk saat ini perencanaan yang saya buat belum dalam bentuk panduan khusus supervisi tetapi masih menggunakan panduan dari dinas yang diberikan pengawas', (wawancara tanggal 21 Desember 2015). Padahal, berdasarkan data yang diperoleh kepala sekolah telah melakukan observasi KBM serta sharing bersama guru sebagai studi pendahuluan dalam melakukan perencanaan supervisi. Hal tersebut menunjukkan belum adanya tindak lanjut dari kepala sekolah dalam membuat perencanaan supervisi berdasarkan observasi dan sharing yang telah dilakukan.

Masalah kedua dalam perencanaan, belum adanya kompetensi khusus yang ingin dicapai dalam supervisi. Kepala sekolah mengungkapkan bahwa:

Untuk saat ini belum ada kompetensi guru secara khusus yang ingin dicapai tetapi lebih berfokus pada pengimplementasian kurikulum 2013 yaitu kompetensi dalam merencanakan kegiatan pembelajaran dan pelaksanaan kegiatan pembelajaran yang secara tidak langsung akan mengevaluasi sampai dimana kompetensi guru dalam implementasi kurikulum 2013 yang berkaitan dengan perencanaan maupun pelaksanaan kegiatan pembelajaran', (wawancara tanggal 21 Desember 2015).

Hal yang sama disampaikan oleh guru kelas, jika kompetensi supervisi yang ingin dicapai yaitu administrasi dan pengelolaan kelas (kuesioner guru kelas, 2016). Hal ini menunjukkan fokus dari perencanaan supervisi hanya pada perencanaan dan pelaksanaan pembelajaran. Padahal, berdasarkan data yang diperoleh tentang penilaian kompetensi pedagogik guru kelas SD Kristen Tunas Gloria. Indikator yang paling rendah terletak pada penilaian dan evaluasi dengan rerata 2,36 dari skor 4 untuk 11 orang guru kelas.

Masalah ketiga, sumber dari dinas yang digunakan sebagai acuan dalam perencanaan belum memadai. Seperti yang diungkapkan oleh kepala sekolah:

Panduan yang diperoleh dari dinas hanya berupa instrumen pelaksanaan sedangkan dalam pelaksanaan supervisi berkaitan dengan kurikulum 2013 yang di dalamnya banyak item yang saya dan guru sendiri belum begitu paham. Sedangkan panduan dari yayasan masih menggunakan panduan supervisi tahun 2012 yang belum terintegrasi dengan kurikulum 2013. (wawancara tanggal 21 Desember 2015).

Masalah keempat dalam perencanaan supervisi, beban pekerjaan kepala sekolah dan keterlambatan guru dalam membuat RPP karena proses pendistribusian buku terlambat. Seperti yang diungkapkan kepala Sekolah:

' kendalanya berupa beban waktu, yaitu tugas dan tanggung jawab sebagai saya kepala sekolah. Kemudian selain kesibukan sebagai kepala sekolah saya juga sedang melanjutkan studi S2 di UNIKA sehingga cukup menyita waktu saya karena harus mengikuti perkuliahan dan mengerjakan tugas kuliah Faktor lain yang menjadi kendala yaitu keterlambatan pada distribusi buku pegangan yang 
membuat guru telat dalam membuat RPP, hal ini menjadi hambatan bagi saya dalam melakukan perencanaan supervisi', (wawancara tanggal 21 Desember 2015).

Dalam pelaksanaan supervisi, masalah yang ditemukan yaitu supervisi belum dilakukan secara berkala dan menyeluruh. Hal ini dikarenakan masih berdasarkan kebutuhan mendesak sesuai dengan masalah guru yang terjadi maupun berdasarkan informasi pelaksanaan supervisi dari dinas. Hal ini dikemukakan kepala sekolah bahwa:

Pelaksanaan supervisi yang saya lakukan belum dilakukan secara berkala. Dikarenakan waktu dan kesibukan saya sebagai kepsek seperti rapat, pembuatan administrasi dari dinas dan sebagainya. Selain itu berkaitan dengan masalahmasalah dalam kelas yang tak terduga yang harus diselesaikan. Jadi supervisi administrasi yang saya lakukan ini berdasarkan kebutuhan yang mendesak'. (wawancara tanggal 21 Desember 2015).

Selain permasalahan di atas, pelaksanaan supervisi untuk semester 2 tahun 2016 baru dilakukan terhadap 3 orang guru kelas, yaitu guru kelas 1, 2, dan 4. Berdasarkan hasil supervisi kepala sekolah respon yang diberikan oleh guru terbilang baik. Hasil supervisi dari "guru kelas 1 mendapat skor 70 dan perlu perbaikan metode pengajaran. Guru kelas 2 mendapat skor 72 dan perbaikannya untuk lebih kreatif dalam metode pembelajaran. Sedangkan guru kelas 4 mendapat skor 75 dan perbaikan terletak pada administrasi penilaian”. (Instrumen Perencanaan Kegiatan Pembelajaran SDK TG).

Permasalahan yang ditemukan dalam evaluasi yaitu masih kurangnya pemahaman kepala sekolah dalam melakukan evaluasi terkait dengan implementasi kurikulum 2013. Berikut yang disampaikan oleh kepala sekolah:

'Iya ada kendala. kendala internal pemahaman saya tentang cara melakukan evaluasi yang benar terkait dengan kurikulum 2013, sehingga saya harus mencari format penilaiannya seperti apa kemudian sharing dengan beberapa teman kepala sekolah akan tetapi waktu sharing yang saya lakukan ini terbilang masih sangat terbatas". (wawancara tanggal 21 Desember 2015).

2. Pengumpulan Data

Tahapan pengumpulan data dilakukan melalui book survay. Berdasarkan hasil book survay, komponen supervisi yang dimasukkan dalam model supervisi teknik mentoring antara lain antara lain, konsep dan teknik supervisi. Mentoring terdiri dari, konsep mentoring, peran mentor dan mentee, tahapan dalam melakukan mentoring yang dikembangkan dari Mentoring the Center for Health Leadership \& Practice, Public Health Institute, for the State Health Directors Executive Mentoring and Consultation Program of the State Health Leadership Initiative (SHLI) Oakland, CA (2003). Sedangkan untuk instrumen penilaian dan evaluasi dikembangkan dari instrumen Dinas Pendidikan dan Kebudayaan Nusa Tenggara Timur Bidang Pendidikan Dasar 2015. 
Pengembangan Model Supervisi Akademik Teknik Mentoring Bagi Pembinaan Kompetensi Pedagogik Guru Kelas | Nehtry E M Merukh \& Bambang Suteng Sulasmono

3. Desain Produk

Model disusun berdasarkan analisis supervisi, konsep mentoring, peran mentor dan mentee, tahapan mentoring, instrumen dari dinas terkait penilaian dalam kurikulum 2013. Berikut disajikan model supervisi akademik teknik mentoring: a) Supervisi Akademik Supervisi akademik merupakan sebuah kegiatan atau pembinaan kepada guru untuk meningkatkan kemampuan profesional dalam pencapaian tujuan profesional. Fokus model supervisi akademik yaitu kompetensi pedagogik tentang penilaian pembelajaran peserta didik. Jenis penilaian yang dimaksud antara lain: penilaian otentik, penilaian diri, penilaian berbasis portofolio, ulangan, ulangan harian, ulangan tengah semester, dan ulangan akhir semester, b) Konsep Mentoring, mentoring dalam model supervisi yaitu hubungan komunikasi antara mentor (orang yang berpengalaman) untuk memberikan bantuan maupun dukungan kepada mentee (orang yang kurang berpengalaman) terkait dengan pekerjaan, karir, dan pengembangan professional. Mentoring di sini merupakan sebuah bentuk bantuan dari kepala sekolah terhadap guru kelas untuk mengembangkan kompetensi pedagogik dalam hal penilaian dan evaluasi. Pelaksanaan mentoring dapat dilakukan secara formal maupun informal berdasarkan kebutuhan di lapangan. Karena mentoring merupakan bimbingan secara individu sehingga bentuk pelaksanaannya dapat dilakukan berdasarkan kesepakatan antara mentor dan mentee. Hal ini bertujuan untuk menciptakan suasana akrab antara mentor dan mentee, c) Peran Mentor, Peran mentor menggambarkan tugas dan tanggung jawab mentor dalam mentoring. Penjelasan peran mentor bertujuan untuk memberikan pemahaman apa fungsi mentor, apa yang harus dikerjakan oleh seorang mentor dan bagaimana bertindak sebagai mentor. Tugas mentor dalam pelaksanaan mentoring antara lain:(1) menolong mentee dalam mengembangkan rencana pembelajaran berupa membangun tujuan tentang apa yang belum bisa dicapai oleh mentee; (2) menyediakan pedoman berdasarkan pembelajaran dan pengembangan kebutuhan mentee; (3) memberikan saran yang tepat kepada mentee dalam mengembangkan pengetahuan dan keahlian; (4) membangun lingkungan belajar yang mendukung pengambilan risiko dan inovasi, dan mendorong mentee untuk memperluas kemampuannya; (5) pendengar yang aktif dan akomodatif; (6) Memberikan umpan balik yang berkaitan dengan bimbingan, d) Peran Mentee, mentee berperan sebagai orang yang dibantu atau diajari oleh mentor dalam mengembangkan kompetensi nya. Walaupun dalam pelaksanaan mentee hanyalah orang yang dianggap pasif (hanya menerima ajaran maupun masukan). Akan tetapi, dalam mentoring seorang mentee pun dituntut aktif dalam perencanaan, pelaksanaan maupun feedback dari mentoring dan memahami akan peran serta 
fungsinya. Hal ini bertujuan untuk memudahkan mentor dalam menjalankan tugas serta fungsinya karena baik mentee maupun mentor sudah memiliki pemahaman akan tugas dan peran dari masing-masing. Tugas dan peran mentee antara lain: (1) mengikuti pembelajaran secara serius; (2) menyelesaikan tugas sesuai dengan rencana yang dinegosiasikan dengan mentor; (3) menunjukkan kebutuhan secara jelas; (4) menolong dalam mengidentifikasi perkembangan tujuan; (5) mencari masukan dari mentor; (6) menunjukkan komitmen melalui tindakan; (7) memelihara kepercayaan diri; (8) memelihara tindakan yang positif; (9) berpikiran terbuka dalam menerima umpan balik baik positif maupun negatif, e) Kunci Keberhasilan Mentoring, Kunci keberhasilan dari mentoring terletak pada bagaimana membangun hubungan antara mentor dan mentee, adanya hubungan saling percaya, peduli, dan saling mendukung. Dalam membangun hubungan antara mentor dan mentee ada beberapa hal yang perlu diperhatikan terkait fungsi dan peran dari mentor dan mentee itu sendiri antara lain: (1) menjadi pendengar yang baik ketika salah satu pihak berbicara; (2) menghindari sikap mendominasi terutama ketika berbicara; (3) kesepakatan dalam mentoring harus dilakukan dalam tindakan; (4) melakukan tinjauan kembali tentang keputusan yang diambil secara bersama; (5) memberikan kesan yang baik terutama kesan pertama dalam melakukan mentoring; (6) menciptakan kebersamaan dalam aktivitas yang dapat dilakukan bersama. Faktor lain yang perlu diperhatikan yaitu penetuan tujuan yang jelas dan terukur. Tujuan yang jelas menggambarkan arah dari mentoring dalam hal apa dan bagaimana. Tujuan yang terukur memberikan masukan kepada mentor dan mentee dapat menetapkan langkah atau cara yang dapat ditempuh untuk pencapaian tujuan. Selain penetuan tujuan, komitmen wajib dimiliki oleh mentor dan mentee dalam pelaksanaan mentoring. Hal ini karena tugas dan tanggung jawab dari mentee maupun mentor yang tidak hanya berfokus pada mentoring tetapi juga pada pekerjaan lain. Penentuan waktu untuk bertemu, sharing ataupun bekerja perlu disepakati bersama oleh mentor dan mentee. Dengan demikian mentoring dapat berjalan secara teratur. f) Tahapan Supervisi Akademik Teknik Mentoring, Tahapan supervisi akademik teknik mentoring terdiri atas 5 tahapan antara lain: 1) Membangun Hubungan, Dalam tahap ini, kepala sekolah sebagai supervisor dan guru selaku supervisee mulai membangun hubungan saling percaya. Hubungan saling percaya satu dengan yang lain dilakukan dengan mengadakan pertemuan untuk membahas masalah, kepentingan dan harapan, 2) Bertukar informasi dan menentukan tujuan, tahapan ini ditandai oleh keterbukaan dan kepercayaan dan diskusi bermakna. Proses bertukar informasi dilakukan melalui wawancara dengan supervisee. Wawancara sebagai bentuk bertukar infomasi tentang jenis serta teknik penilaian yang digunakan oleh guru kelas, bagaimana tahapan dalam 
Pengembangan Model Supervisi Akademik Teknik Mentoring Bagi Pembinaan Kompetensi Pedagogik Guru Kelas | Nehtry E M Merukh \& Bambang Suteng Sulasmono

melaksanakan penilaian serta kendala yang dihadapi dalam melakukan penilaian. Selain wawancara, tahapan penentuan tujuan (goal setting) akan ditentukan sendiri oleh supervisee dengan bantuan dari supervisor jika dibutuhkan. Supervisee dapat menuliskan kompetensi yang ingin dicapai, manfaat dari supervisi, mencari tau kendala yang akan menghambat pelaksanaan supervisi serta sumber yang dibutuhkan oleh supervisee dalam pelaksanaan supervisi, 3) Bekerja ke arah tujuan, Dalam tahap ini supervisor memberikan dorongan dan motivasi untuk mencapai tujuan supervisi. Bentuk pelaksanaan dilakukan pemberian materi dan tugas oleh kepala sekolah terhadap guru kelas berdasarkan kebutuhan. 4) Evaluasi (Penentuan Akhir Supervisi), tahap ini supervisor dan supervisee akan saling mengevaluasi tentang pelaksanaan supervisi dan kompetensi dari supervisor maupun supervisee. Tahap keempat dalam model supervisi dilampirkan form penilaian kompetensi pedagogik guru kelas dan juga penilaian pelaksanaan supervisi dan supervisor oleh guru kelas. Selain penilaian, terdapat wawancara supervisor terhadap supervisee untuk mendapat feedback terkait pelaksanaan supervisi. Panduan wawancara memuat ketercapaian tujuan (goal setting) supervisi, hal-hal yang masih dirasa kurang dalam pelaksanaan, kesulitan dalam pelaksanaan supervisi, alternatif lain dalam pelaksanaan maupun saran serta masukan untuk supervisi yang akan datang jika masih dibutuhkan. 5) Tindak Lanjut (Perencanaan Masa Depan) tahap ini dapat dilakukan jika goal setting supervisi belum tercapai, bentuk tindak lanjut yaitu kepala sekolah dan guru kelas kembali pada tahap 1 (membangun hubungan).

4. Validasi Produk

Validasi dilakukan oleh Prof. Dr. Slameto, M.Pd, Dr. Bambang Ismanto, M.Si, dan Kepala sekolah SD Kristen Tunas Gloria Kupang Frengky Lesse, S.Pd. Validasi dilakukan menggunakan teknik delphi melalui media kuisioner yang dilakukan sebanyak 2 putaran oleh Prof. Dr. Slameto, M.Pd dan Dr.Bambang Ismanto, M.Si sedangkan 1 putaran oleh Frengky Lesse, S.Pd . Validasi tersebut memberikan hasil sebagai berikut:

a. Prof. Dr. Slameto, M.Pd

Berdasarkan validasi terhadap draft desain model supervisi akademik teknik mentoring terdapat beberapa hal yang perlu diperbaiki yaitu penjabaran pentingnya model, sistematika penulisan, tahapan 4 (evaluasi supervisi), penyajian bagan pelaksanaan dan penambahan petunjuk pada instrumen pendukung supervisi.

b. Dr. Bambang Ismanto, M.Si

Berdasarkan validasi terhadap draft desain model supervisi teknik mentoring terdapat beberapa hal yang perlu diperbaiki, yaitu penjabaran situasi problematis pada latar belakang, 
penjelasan tujuan dan output pada setiap tahapan, tahapan 4 (evaluasi) bagaimana tindak lanjut dan instrumen pertanyaan wawancara.

c. Frengky Lesse, S.Pd

Berdasarkan validasi terhadap draft model secara keseluruhan cukup jelas dan mudah dipahami.

\section{Perbaikan Produk}

Berdasarkan validasi desain oleh para ahli maka dilakukan perbaikan sebagai berikut: a) Penjabaran latar belakang dipertajam dengan menambahkan pentingnya model dan situasi problematik di SD Kristen Tunas Gloria Kupang, b) Struktur model diubah dengan menambahkan kajian teori tentang model supervisi akademik teknik mentoring, c) Tahap pada evaluasi supervisi (penentuan akhir supervisi) di follow up dengan kegiatan tindak lanjut (perencanaan masa depan), d) Setiap instrumen pendukung model supervisi ditambahkan petunjuk penggunaan dan pertanyaan wawancara dirinci agar setiap nomor hanya berisi satu pertanyaan.

\section{URAIAN MODEL}

Model supervisi akademik teknik mentoring dilandasi oleh Permendiknas RI Nomor 13 Tahun 2007 tentang Standar Kualifikasi Akademik dan Kompetensi Kepala Sekolah/ Madrasah yang menyebutkan salah satu dimensi kompetensi kepala sekolah yaitu supervisi. Kedua Permendiknas RI Nomor 16 Tahun 2007 tentang Standar Kualifikasi Akademik dan Kompetensi Guru yang menyebutkan kompetensi pedagogik wajib dimiliki guru. Kedua landasan tersebut menjadi latar belakang terbentukknya tujuan. Dalam model ini, subyek yang akan dituju adalah guru kelas yang nantinya akan mendapat supervisi kepala sekolah.

Model supervisi akademik ini menggunakan teknik mentoring sehingga dalam pelaksanaannya kepala sekolah menjalankan peran seperti mentor dan guru sebagai mentee. Mentoring yang dimaksud adalah hubungan komunikasi kepala sekolah dan guru yang dalam implementasinya kepala sekolah memberikan bantuan serta bimbingan untuk mengembangkan kompetensi guru. Hubungan ini memungkinkan pembelajaran 2 arah walaupun tidak seimbang antara yang diperoleh mentee dan mentor. Model ini memungkinkan mentee berperan aktif untuk menentukan sendiri tujuan supervisi berdasarkan kebutuhan guru tersebut.

Secara umum, model ini terdiri atas 4 tahap kegiatan yaitu perencanaan, pelaksanaan, evaluasi dan tindak lanjut. Tahap perencanaan dilakukan melalui tahapan membangun hubungan, bertukar informasi dan pengisian goal setting. Tahap pelaksanaan 
Pengembangan Model Supervisi Akademik Teknik Mentoring Bagi Pembinaan Kompetensi Pedagogik Guru Kelas | Nehtry E M Merukh \& Bambang Suteng Sulasmono

merupakan proses bekerja ke arah tujuan. Tahap evaluasi merupakan proses penilaian pelaksanaan supervisi dan tindak lanjut sebagai akibat dari evaluasi goal setting supervisi yang belum tercapai.

Membangun hubungan, pada tahap ini kepala sekolah melakukan komunikasi dengan guru kelas terkait masalah, kepentingan, dan harapan. Pertanyaan yang dapat ditanyakan oleh kepala sekolah antara lain: a) ceritakan tentang diri bapak/ibu, tentang kemampuan dalam melakukan penilaian, (b) bagaimana pelaksanaan penilaian selama ini, c) apa kendala dalam melakukan penilaian terhadap peserta didik, d) bagaimana bapak/ibu mendapatkan keuntungan dari hubungan supervisi, (e) apa tujuan utama bapak/ibu dalam hubungan supervisi ini. Kotze (2014) menyebutkan membangun hubungan membuka ruang untuk supervisor dan supervisee menemukan titik tolak dari permasalahan . Muslim (2010) menyebutkan salah satu tahapan dalam pelaksanaan supervisi yaitu membangun komunikasi pribadi. Tahap ini lebih ditekankan bagaimana terciptanya hubungan saling percaya antara supervisor dan supervisee. Pada akhir tahap ini diharapkan terciptanya hubungan saling percaya antara supervisor dan supervisee yang ditandai dengan adanya keterbukaan supervisee dalam menyampaikan kemampuan dan kekurangannya.

Bertukar informasi dan pengisian goal setting, tahap bertukar informasi dilakukan melalui wawancara kepala sekolah terhadap guru kelas. Dalam proses wawancara dapat terjadi proses sharing terkait masalah atau kendala yang dihadapi guru. Kemudian dilanjutkan dengan pengisian form goal setting oleh guru kelas. Akhir tahapan ini, ditandai dengan perumusan tujuan supervisi yang spesifik berdasarkan hasil wawancara dan form goal setting yang telah diisi. Tahap ini sejalan dengan penelitian Widyasari dan Yaumi (2014) yang menyebutkan tahap perencanaan mencakup penjabaran tujuan pendampingan, mengidentifikasi potensi guru serta menfasilitasi orientasi bersama. Proses ini memberikan kesempatan untuk guru berperan aktif dalam perencanaan. Hal ini didukung oleh model pengembangan Prihono (2014) yang mana pengawas meminta masukan tentang kebutuhan kompetensi guru dan bentuk perencanaan dilakukan bersama oleh pengawas dan guru.

Bekerja ke Arah Tujuan, tahap ini merupakan proses kerjasama antara supervisor dan supervisee untuk mencapai tujuan. Bentuk kerja sama dilakukan melalui percakapan, materi tertulis, tugas dan mencoba berbagai kegiatan pembelajaran. Tahap ini lebih ditekankan pada bantuan atau bimbingan yang diberikan oleh kepala sekolah. Modrcin (dalam Suhardan, 2010) menyebutkan salah satu fungsi supervisor yaitu teaching function, menyediakan informasi baru yang relevan dengan tugas yang harus dilaksanakan. Selanjutnya kepala sekolah sebagai supervisor perlu memberikan dorongan terhadap 
supervisee dan merefleksikan kemajuan menuju tujuan dan pada hubungan supervisi itu sendiri. Supervisor dan supervisee dapat membahas hal-hal berikut: a) apa manfaat dari hubungan supervisi sampai saat ini, b) perubahan apa yang bapak/ibu lihat pada diri sendiri dalam cara melakukan penilaian sebagai akibat dari hubungan supervisi, c) jika ada, jenis penyesuaian atau perubahan apa yang dibutuhkan dalam hubungan supervisi. Pada akhir tahapan ini, diharapkan supervisor telah memberikan materi atau tugas yang sesuai dengan goal setting yang dirumuskan dan berdasarkan kebutuhan guru. Hal tersebutu didukung oleh Sagala (2010) yang menyebutkan bahwa pencapaian supervisi dapat diraih dengan latihan sesuai kebutuhan dan keperluan guru.

Penentuan Akhir Supervisi, tahap ini merupakan tahap evaluasi yang menentukan hubungan supervisi berakhir atau dilanjutkan dengan perencanaan supervisi yang baru. Jika hasil evaluasi menunjukkan goal setting tercapai maka supervisi dapat diakhiri. Maruta et al (2013) menyebutkan keberhasilan progaram dengan melakukan pengukuran kemajuan. Bentuk evaluasi dilakukan oleh kepala sekolah dengan menggunakan instrumen penilaian kompetensi guru serta melakukan wawancara tentang pelaksanaan supervisi. Evaluasi tidak hanya dilakukan oleh kepala sekolah selaku supervisor terhadap guru kelas. Guru sebagai supervisee juga diberikan kesempatan untuk melakukan evaluasi. Bentuk evaluasi guru dengan mengisi instrumen penilaian pelaksanaan supervisi dan penilaian supervisor. Hasil keseluruhan evaluasi diberikan oleh kepala sekolah kepada guru kelas dalam bentuk raport dan sebalikanya guru kelas memberikan form penilaian pelaksanaan supervisi dan penilaian supervisor kepada kepala sekolah. Kedua form ini yang akan digunakan sebagai tolak ukur untuk mengakhiri supervisi.

Perencanaan Masa Depan, tahap ini merupakan bentuk tindak lanjut dari hasil evaluasi supervisi yang menunjukkan belum tercapainya goal setting. Pada tahap ini supervisor dan supervisee akan memulai dengan perencanaan masa depan (supervisi baru) dan kembali ke tahap 1. Dalam penelitian Widyasari dan Yaumi (2014) menyebutkan bentuk tindak lanjut evaluasi dengan mendesain kembali program pendampingan. Selanjutnya supervisor bekerja sama dengan supervisee untuk menentukan jenis dukungan yang mungkin diperlukan di masa depan. Selain itu, supervisor juga dapat menghubungkan supervisee dengan rekan-rekan lain yang dapat memberikan manfaat berupa informasi, pengetahuan lain di luar yang disediakan oleh supervisor. Hal tersebut mengacu pada model supervisi Ernawati (2014) yang menggunakan teknik kunjungan kelas oleh guru senior. Akan tetapi model ini berfokus pada guru yang telah lulus dari pelaksanaan supervisi akan diperbantukan 
Pengembangan Model Supervisi Akademik Teknik Mentoring Bagi Pembinaan Kompetensi Pedagogik Guru Kelas | Nehtry E M Merukh \& Bambang Suteng Sulasmono

dalam supervisi kepala sekolah. Ernawati menyebutkan bentuk tindak lanjut dalam model supervisi berupa kegiatan pembinaan dan perbaikan terkait kompetensi guru. Tahap ini memungkinkan diskusi antara supervisor dan supervisee antara lain: a) menemukan jenis dukungan yang mungkin masih diperlukan, b) mendiskusikan apakah hubungan akan berlanjut secara informal dan bagaimana supervisor dan supervisee akan menerapkannya.

\section{SIMPULAN DAN SARAN}

Berdasarkan hasil penelitian yang telah dikemukan sebelumnya , maka dapat disimpulkan halhal berikut:

1. Pelaksanaan supervisi di SDK Tunas Gloria diawali dengan melakukan observasi dan sharing bersama guru sebagai bentuk perencanaan. Pada tahap pelaksanaan, supervisi belum memiliki tujuan khusus pencapaian kompetensi berdasarkan kebutuhan guru. Supervisi yang telah dilakukan yaitu supervisi perencanaan kegiatan pembelajaran dan observasi kelas dan baru dilakukan terhadap 3 orang guru kelas yaitu guru kelas 1, guru kelas 2 dan guru kelas 4. Bentuk tindak lanjut yang dilakukan sebagai hasil dari evaluasi kepala sekolah masih dalam saran pembinaan tertulis yang disampaikan melalui instrumen pelaksanaan supervisi.

2. Masalah yang ditemukan dalam pelaksanaan supervisi di SDK Tunas Gloria Kupang antara lain: Pertama, belum ada perencanaan tertulis yang dibuat oleh kepala sekolah sebagai hasil dari observasi dan sharing bersama guru. Kedua, penentuan tujuan supervisi belum berdasar pada kebutuhan guru. Ketiga, Panduan yang digunakan oleh kepala sekolah (panduan supervisi yayasan \& instrumen pelaksanaan supervisi dinas) belum memadai. Keempat, beban kerja kepala sekolah yang menyebabkan perencanaan belum dilakukan secara baik dan pelaksanaan supervisi belum dilakukan secara berkala. Kelima, Pelaksanaan supervisi dilakukan berdasarkan informasi pelaksanaan supervisi dari dinas sehingga hanya dilakukan pada guru tertentu yang akan mendapat supervisi pengawas. Keenam, kurangnya pemahaman kepala sekolah dalam melakukan evaluasi. Sehingga belum ada tindakan tindak lanjut yang dilakukan oleh kepala sekolah sebagai hasil evaluasi.

3. Model supervisi akademik teknik mentoring memberikan kesempatan kepada supervisor dan supervisee untuk bekerja sama dan aktif dalam pelaksanaan supervisi. Model yang dikembangkan disesuaikan dengan tahap pelaksanaan supervisi akademik dan ditunjang instrumen pendukung dimulai dari perencanaan, pelaksanaan, evaluasi dan tindak lanjut. 
1. Kepala sekolah dapat menggunakan model supervisi akademik teknik mentoring pembinaan kompetensi pedagogik guru kelas dalam melakukan perencanaan, pelaksanaan, evaluasi dan tindak lanjut supervisi.

2. Peneliti yang ingin mengembangkan produk lebih lanjut dapat memuat semua karakteristik kompetensi pedagogik dan dilanjutkan sampai tahap uji coba tidak terbatas hanya pada tahap revisi desain.

\section{DAFTAR PUSTAKA}

Chick, T.A.et al., 2013. Team Software Process (TSP) Coach Mentoring Program Guidebook, Version 2.0. Hanscom AFB MA: Camegie Mellon University.

Center for Health Leadership \& Practice. 2003. Mentoring Guide (A Guide for Mentors). Ethics in Science and Engineering National Clearinghouse. Paper 304.

Danim, S. 2010. Inovasi Pendidikan: Dalam Upaya Peningkatan Profesionalisme Tenaga Kependidikan. Bandung: Pustaka Setia.

Departemen Pendidikan Nasional, 2005. Undang-Undang Republik Indonesia No.14 Tahun 2005 Tentang Guru dan Dosen. Jakarta: Depdiknas.

Ernawati. 2014. Pengembangan Model Supervisi Akademik dengan Teknik Kunjungan Kelas Berbasis Guru Senior Pada Guru TIK SMA Kota Semarang. Educational Management Journal UNNES 3 (1). 41-46.

Kotze, E. 2014. Movements in The Academic Supervision Relationship: Ethics in Practice. Counselling and Psychoterapy Research 14 (2). 147-15.

Mailani, E. 2014. Upaya Pembinaan Kompetensi Pedagogik Guru Dalam Menyusun Rencana Pelaksanaan Pembelajaran Melalui Kegiatan Pendampingan (Mentoring). School Education Journal PGSD FIP UMIMED. 1(2). 35-41.

Maruta et al., 2013. Setting up a Structured Laboratory Mentoring Programme. AOSIS Open Journal, 2 (1) 1-7.

Mukhtar \& Iskandar. 2009. Orientasi Baru Supervisi Pendidikan. Jakarta: Gaung Persada Press.

Mulyasa, H.E. 2013. Uji Kompetensi dan Penilaian Kinerja Guru.Bandung: PT Remaja Rosdakarya.

Muslim, S.B. 2010. Supervisi Pendidikan Meningkatkan Kualitas Profesionalisme Guru. Bandung: Alfabeta. 
Pengembangan Model Supervisi Akademik Teknik Mentoring Bagi Pembinaan Kompetensi Pedagogik Guru Kelas | Nehtry E M Merukh \& Bambang Suteng Sulasmono

Prihono, H. 2014. Model Supervisi Akademik Bebasis Evaluasi Diri Melalui MGMP Sekolah Untuk Meningkatkan Kompetensi Pedagogik Guru SMK Di Kabupaten Wonogiri. Educational Management Journal UNNES 3 (2). 127-132.

Sagala. 2010. Supervisi Pembelajaran dalam Profesi Pendidikan. Bandung: Alfabeta.

Sharma, S, et al. 2011. "Concerns of Teachers and Principals on Instructional Supervision in Three Asian Countries." International Journal of Social Science and Humanity 1 (3). $214-217$

Slameto. 2013. Implementasi Eksplorasi, Elaborasi, dan Konfirmasi dalam Pembelajaran Guna Meningkatkan Kompetensi Pedagogik Guru SD. Salatiga: Tisara Grafika.

Sugiyono. 2009. Metode Penelitian Kuantitatif, Kualitatif dan $R \&$ D. Bandung :Alfabeta.

Suhardan. 2010. Supervisi Profesional (Layanan dalam Meningkatkan Mutu Pembelajaran di Era Otonomi Daerah). Bandung: Alfabeta.

Widyasari \& Yaumi, M. 2014. Evaluasi Pendampingan Guru SD dalam Implementasi Kurikulum 2013. Lentera Pendidikan. 17 (2). 281-295.

Lampiran 1

Bagan Model Supervisi Akademik Teknik Mentoring Kepala Sekolah 
Tahap 1-2 Perencanaan

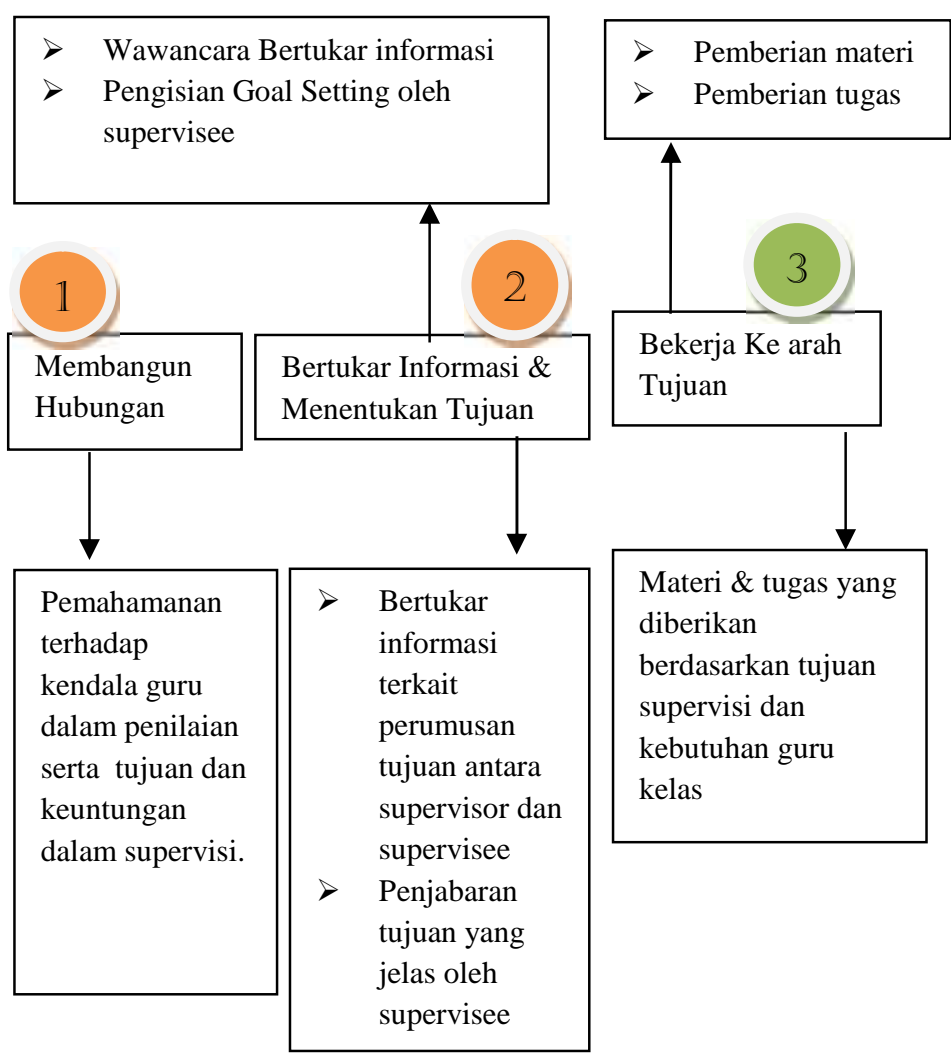

Tahap 4: Evaluasi Tahap 5:

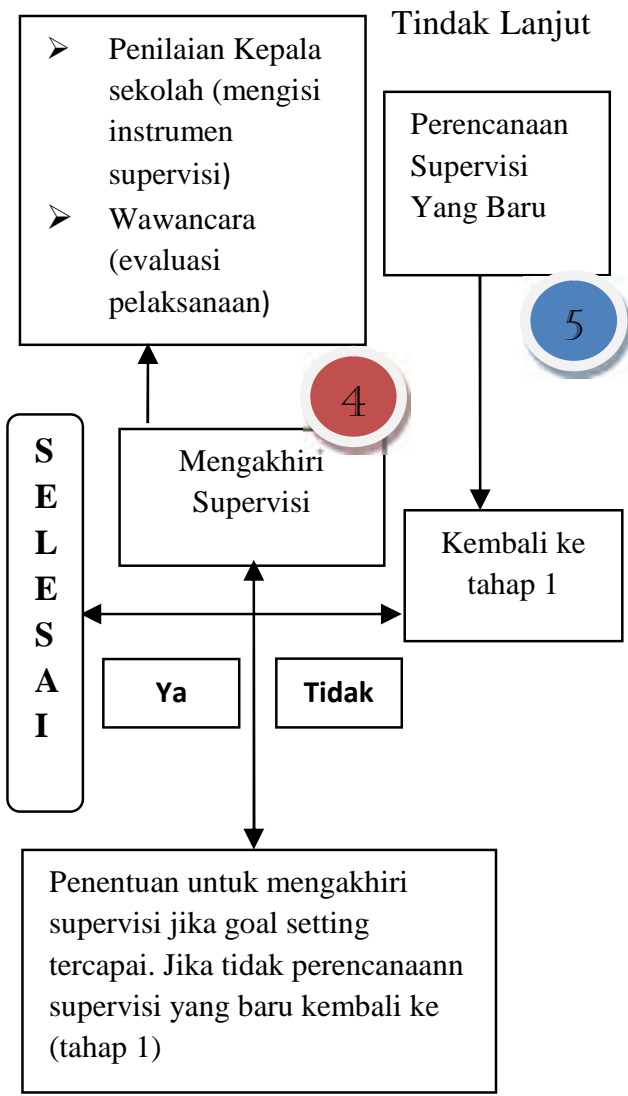

\section{Lampiran 2}

Bagan Model Supervisi Akademik Teknik Mentoring Guru Kelas 
Tahap 1-2 Perencanaan

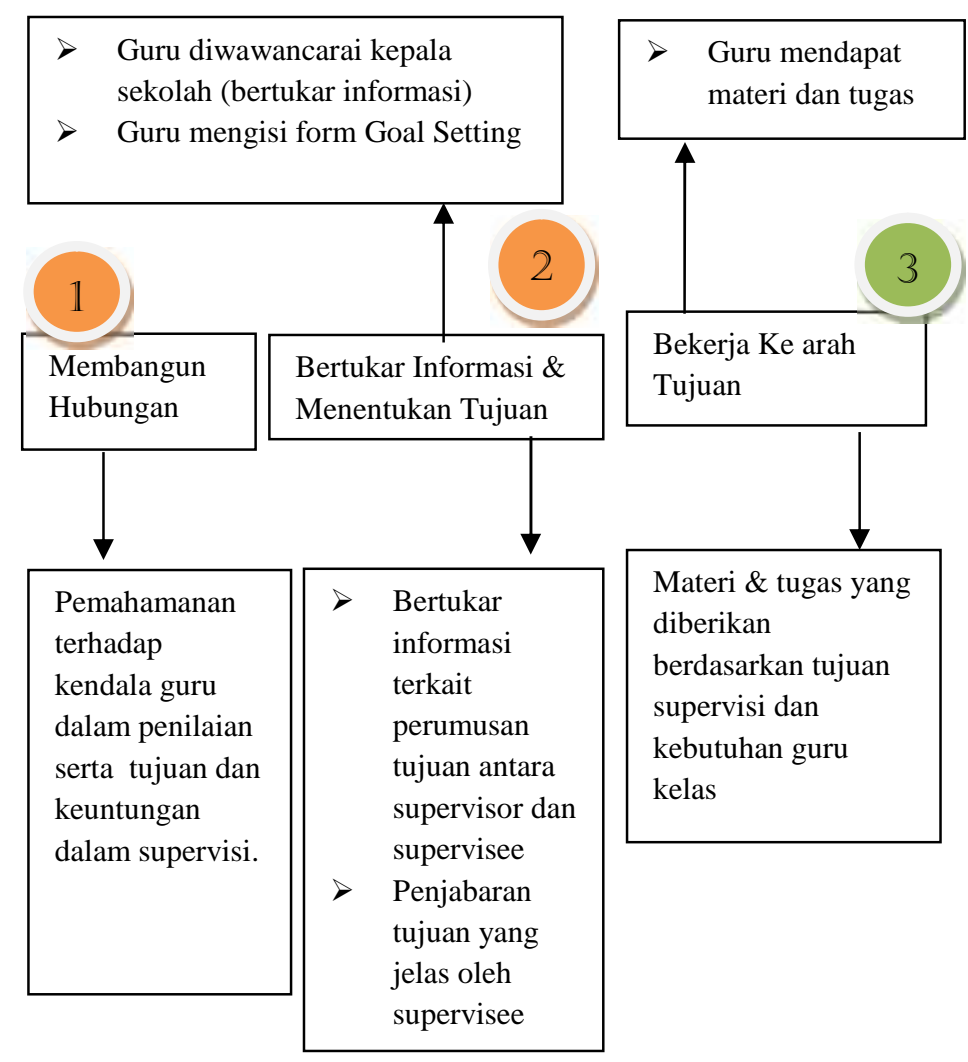

Tahap 4: Evaluasi Tahap 5:

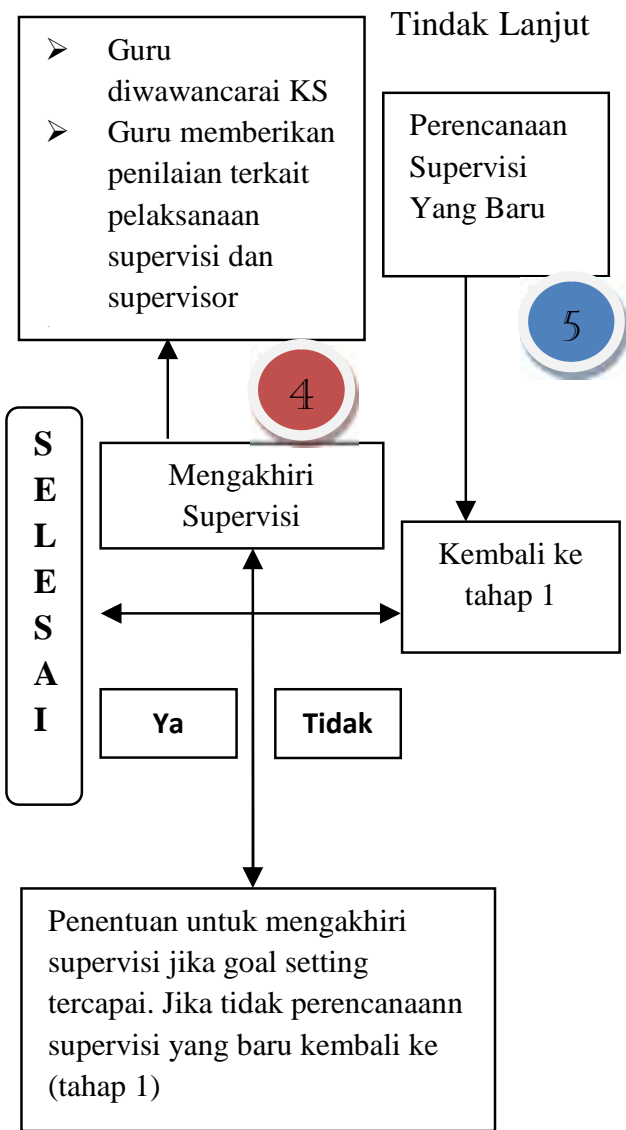

